\title{
Comparative study of inflammatory response and adhesions formation after fixation of different meshes for inguinal hernia repair in rabbits ${ }^{1}$
}

\author{
Estudo comparativo da resposta inflamatória e da formação de aderências após \\ fixação de diferentes tipos de telas para correção de hérnia inguinal em coelhos
}

\author{
Alberto Goldenberg², Jacques Matone ${ }^{3}$, Wagner Marcondes ${ }^{4}$, Fernando Augusto Mardiros Herbella ${ }^{5}$, \\ José Francisco de Mattos Farah \\ 1. Research performed at the Gastrointestinal Division and Experimental Surgery Division of the Federal University of São Paulo - Escola \\ Paulista de Medicina - UNIFESP-EPM. São Paulo, Brazil. \\ 2. Associate Professor, PhD, Gastrointestinal Division - UNIFESP-EPM. São Paulo, Brazil. \\ 3. Senior Resident, Gastrointestinal Division - UNIFESP-EPM. São Paulo, Brazil. \\ 4. Post graduate student - UNIFESP-EPM. São Paulo, Brazil. \\ 5. PhD in Gastrointestinal Surgery - UNIFESP-EPM. São Paulo, Brazil. \\ 6. Post graduate student - UNIFESP-EPM. São Paulo, Brazil.
}

\begin{abstract}
Purpose: Compare, in a rabbit model, the inflammatory response and adhesions formation following surgical fixation of polypropilene and Vypro mesh in the inguinal preperitoneal space. Methods: Fourteen male New Zealand rabbits, weighing between 2.000 to $2.500 \mathrm{~g}$ were used. A midline incision was made and the peritoneal cavity was exposed. The 2,0X1,0 cm polypropylene mesh was fixed in the left flank and secured to the margins with 3-0 prolene in a separate pattern. In the right flank, a 2,0X1,0 cm Vypro II mesh was sewn in the same way. After the post surgical period, the animals were again anesthetized and underwent laparoscopic approach, in order to identify and evaluate adhesions degree. Both fixed prosthesis were excised bilaterally with the abdominal wall segment, including peritoneum, aponeurosis and muscle and sent to a pathologist Results: Operative time ranged from 15 to 25 minutes and no difficulties in applying the mesh were found. From the 14 polypropylene meshes fixed to the intact peritoneum, 11 had adhesions to the abdominal cavity (78,6\%). Concerning Vypro mesh, 12 animals developed adhesions from the 14 with mesh fixation (85,7\%). Histological examination of tissues harvested revealed fibroblasts, collagen, macrophages and lymphocytes between the threads of the mesh. Conclusion: Polypropylene and Vypro mesh, when implanted in the peritoneal cavity of rabbits provoke similar amount of adhesions. Vypro mesh tissues had higher fibrosis resulting in better mesh incorporation to the abdominal wall. Key words: Inguinal hernia. Adhesions. Inflammation. Rabbits.
\end{abstract}

\begin{abstract}
RESUMO
Objetivo: Avaliar a resposta inflamatória e a formação de aderências das próteses de polipropileno e polipropileno associado a poliglactina sintética (Vypro ${ }^{\circledR}$ ) implantadas no espaço pré-peritoneal de coelhos. Métodos: Foram utilizados 14 coelhos albinos linhagem Nova Zelândia com três meses de idade, machos com peso variando de 2000 a 2500 gramas. O acesso à cavidade se deu por incisão mediana abaixo do apêndice xifóide com oito centímetros de extensão. Realizou-se o implante da tela de polipropileno no flanco esquerdo com um ponto de polipropileno em cada extremidade da prótese. No flanco direito a tela Vypro® foi fixada da mesma forma com pontos de polipropileno. A laparoscopia foi realizada 28 dias após o primeiro procedimento para avaliação de aderências intracavitárias. As próteses juntamente com o peritônio, musculatura e aponeurose adjacente foram retiradas em blocos individuais. Cada peça foi imersa em solução tamponada de formaldeido a $10 \%$ e encaminhada ao patologista. Resultados: Todos os animais tiveram boa evolução pós-operatória não havendo infecção das incisões cirúrgicas ou óbito dos coelhos. Das quatorze próteses Prolene implantadas no peritônio intacto de coelho, em onze (78,6\%) houve formação de aderências Das quatorze próteses Vypro® implantadas no peritônio intacto de coelho, em doze (85,7\%) houve formação de aderências. Comparando as duas próteses entre si não houve diferença significante quanto ao numero de aderências formadas. Em relação a avaliação microscópica, nas próteses VYPRO ${ }^{\mathrm{a}} \mathrm{a}$ reação granulomatosa do tipo corpo estranho e a fibrose foram predominantemente moderadas. Já a inflamação inespecífica foi proporcionalmente leve e moderada A inflamação inespecífica foi menos intensa nas próteses de polipropileno. Conclusão: Ambas as próteses implantadas na cavidade peritoneal de coelhos promovem a formação de aderências de forma semelhante. As próteses de polipropileno e associado a poliglactina promovem maior fibrose, apresentando melhor incorporação aos tecidos.
\end{abstract}

Descritores: Hérnia inguinal. Aderências. Inflamação. Coelhos. 


\section{Introduction}

The goals of a successful hernia repair include low recurrence rates, permanent relief of pain or discomfort and low incidence of peri and postoperative complications, such as wound infections and intra abdominal adhesions. The use of prosthetic mesh for the surgical treatment of inguinal hernia has markedly increased during the last decade and it has become routinely applied in some of the major surgical centers of inguinal hernia repair. Due to the resistant mesh implant together with the tension-free technique, recurrence rates have dramatically diminished throughout this period ${ }^{1}$. Besides, the laparoscopic approach demands the fixation of a prosthetic mesh and, in some reports, high rates of intraperitoneal adhesions were found due to the mesh. ${ }^{2,3}$

Polypropylene mesh in the most popular choice for those surgeries thanks to its strength and excellent incorporation characteristics. However, these incorporation qualities provoke a strong stimulus for chronic inflammatory response, as well as for adhesion formation. New biomaterials have been developed in order to reduce this inflammatory process with a reduction in connective tissue formation and, as a result, diminishing abdominal adhesions.

The ever-lasting search for the ideal mesh, which means no side effects related, has led to the development of the Vypro mesh, characterized by a reduction of polypropylene weight and an increase in the pore size associated to supplementary polyglactin filaments to improve intraoperative handling during mesh placement. ${ }^{4}$ It is hypothesized that the reduction of the polypropylene amount may cause less inflammatory reaction and subsequently less abdominal adhesions in the postoperative period. The purpose of this study was to compare, in an animal model, the inflammatory response and adhesions formation following surgical fixation of polypropilene and Vypro mesh in the inguinal preperitoneal space, in rabbits.

\section{Methods}

Fourteen male New Zealand rabbits (Oryctolagus cuniculus), weighing between 2.000 to $2.500 \mathrm{~g}$ were used in this study. The animals were housed under conditions of constant light and temperature and received a complete diet ad libitum throughout the research. For the duration of the study, all animals were caged and maintained in constant light and temperature conditions. The study was performed according to the rules of the Brazilian College of Animal Experimentation (COBEA) and the National Institute of Health (NIH) guidelines for the use of laboratory animals. The animals were cared for only by vet personnel.

Two different prosthesis were evaluated during the study. Prolene (Ethicon ${ }^{\circledR}$, Somerville, New Jersey, USA) and Vypro II mesh (Ethicon ${ }^{\circledR}$, Somerville, New Jersey, USA) were used as received from the manufacturer. The common heavy-weight prolene is a hosiery made of two monofilaments of polypropilene and the low-weight Vypro II mesh with a large pore size is a hosiery built of multifilaments of polypropilene with additional absorbable polyglactin. The animals were fasting for 12 hours prior to the procedure and were preanesthetized with acepromazine $1 \%(0,5 \mathrm{mg}$. im). After ten minutes, all animals were anesthetized with ketamine hydrochloride (30mg/kg, i.m.) and xylazine hydrochloride (10mg/kg, i.m.). The abdomen of each animal was shaved and prepped with povidone/ iodine scrub and successive alcohol wipes. All operative technique was performed in aseptic standards. A $8 \mathrm{~cm}$ midline incision was made, caudal to the xyphoid appendix and the peritoneal cavity was exposed. The 2,0X1,0 cm polypropylene mesh was fixed in the left flank and secured to the margins with 3-0 prolene in a separate pattern. In the right flank, a 2,0X1,0 cm Vypro II mesh was sewn in the same way. The abdominal wall was sewn with 2-0 polyglactin simple continuous pattern and the skin closed with 4-0 mononylon thread. Povidone ointment was applied to the incision and a pressure bandage was applied. The animals were allowed to recover in individual cages and were observed for 28 days. They were controlled daily for local and systemic complications throughout the observation period. Every alteration were controlled and pointed out in the protocol resume. After the post surgical period, the animals were again anesthetized and underwent laparoscopic approach, in order to identify and evaluate adhesions degree. The $10 \mathrm{~mm}$ trocar was set $5 \mathrm{~cm}$ caudal to the previous incision for the pneumoperitoneum and introduction of the optic. Another two $5 \mathrm{~mm}$ trocars were placed in the right and left hypocondrium. Abdominal pressure was kept in $10 \mathrm{mmHg}$ and the whole peritoneal cavity was evaluated, principally the sites where meshes were fixed. The findings were recorded to be analyzed by an independent investigator surgeon, who was unaware of the kind of mesh implanted. After the recording phase, laparotomy was performed and both fixed prosthesis were excised bilaterally with the abdominal wall segment, including peritoneum, aponeurosis and muscle. The entire tissue was fixed in $10 \%$ paraformaldehyde and sent to a pathologist. The animals were finally euthanized with endovenous injection of potassium chloride. The degree of adhesions was graded from 0 to 4 using an adhesion scoring scale as described by Shimanuki et al. ${ }^{5}$ In this scoring system, grade 0 represents no adhesion; grade 1 represents scattered filmy adhesions, no difficulty in lysis; grade 2 represents moderately dense adhesions, no difficulty in lysis with discreet bleeding after lysis; and grade 3 represents very dense homogeneous adhesions with difficulties in lysis.

The whole mesh with the surrounding abdominal wall of the right and left flank were stained with hematoxylineosin and examined by the same pathologist in light microscopy. Specimens were processed, embebbed in paraffin, dehydrated in ethanol and sectioned at $4 \mathrm{~mm}$ each and a morphometric evaluation performed by a histopathologist blinded as to the groups.

\section{Results}

The rabbit proved to be a suitable animal for this study. All animals had an uneventful postoperative course. Operative time ranged from 15 to 25 minutes and no difficulties in applying the mesh were found. No wound infections were observed postoperatively. From the 14 polypropylene meshes fixed to the intact peritoneum, 11 had adhesions to the abdominal cavity (78,6\%). (Figure 1) 
Concerning Vypro mesh, 12 animals developed adhesions from the 14 with mesh fixation (85,7\%) (Figure 2). As regards to adhesion formation, there were no significant differences in the amount of adhesions between the groups (Figure 3). However, some differences were observed comparing the grade of adhesions formed. Vypro meshes were principally linked to grade 1 adhesions, while polypropylene meshes were responsible for grade 3 adhesions. There were similar results for grade 2 adhesions (Figure 4).

Figures 5, 6 and 7 show adhesions found during laparoscopy performed in the postoperative period. Histological examination of tissues harvested revealed fibroblasts, collagen, macrophages and lymphocytes between the threads of the mesh. In Vypro mesh side, foreign body granulomatous reaction and fibrosis were moderately found. The inflammatory response was minimal to moderate (Figure 8).

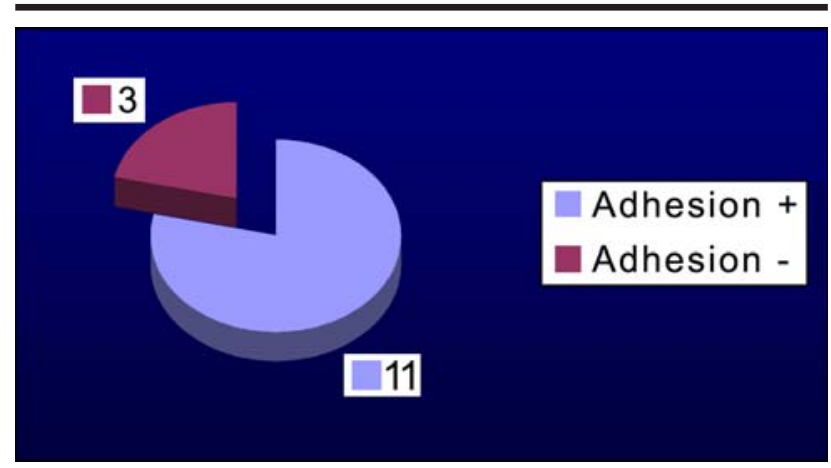

FIGURE 1 - Amount of adhesion formation to polypropylene mesh fixation.

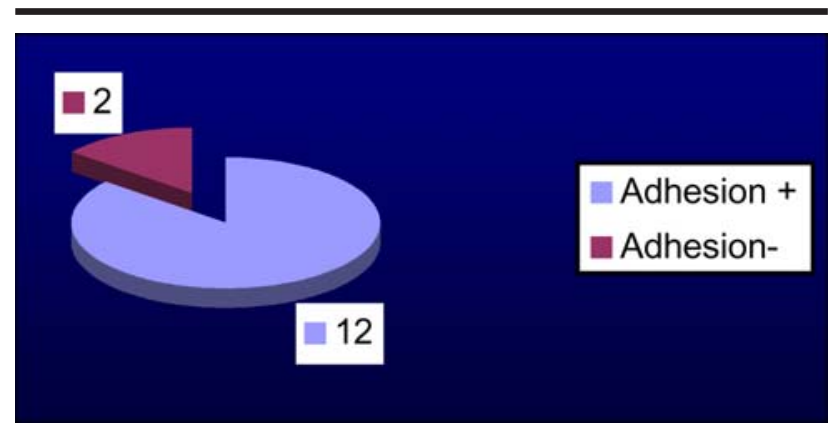

FIGURE 2 - Amount of adhesion formation to Vypro mesh fixation.

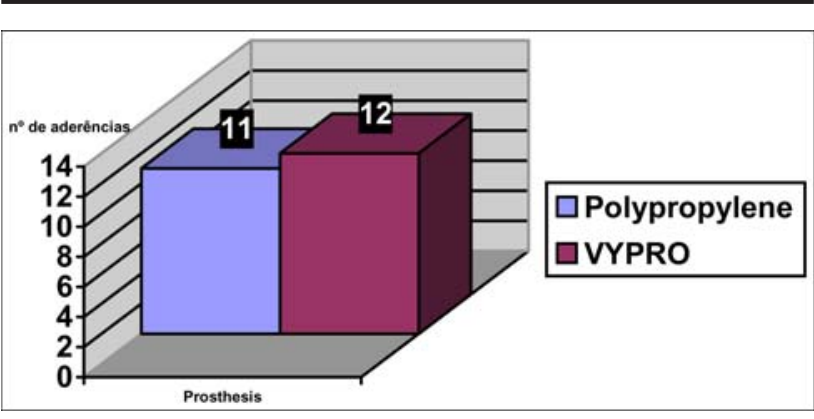

FIGURE 3 - Comparison between polypropylene and Vypro mesh concerning amount of adhesions formation.

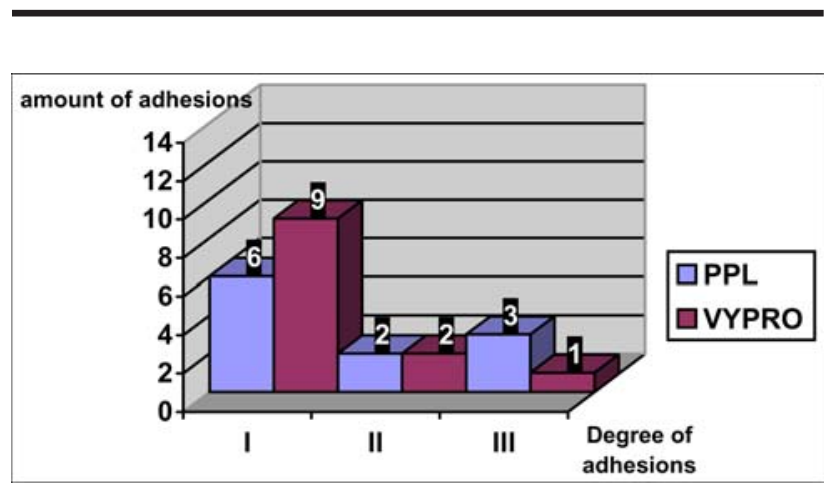

FIGURE 4 - Comparison between polypropylene and Vypro mesh concerning the degree of adhesions formation according to Shimanuki et al. scoring system.

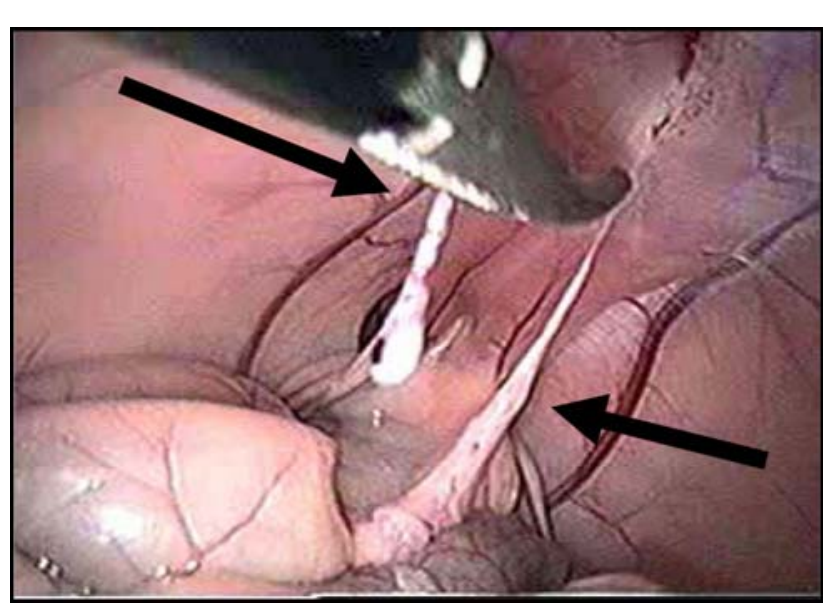

Figure 5

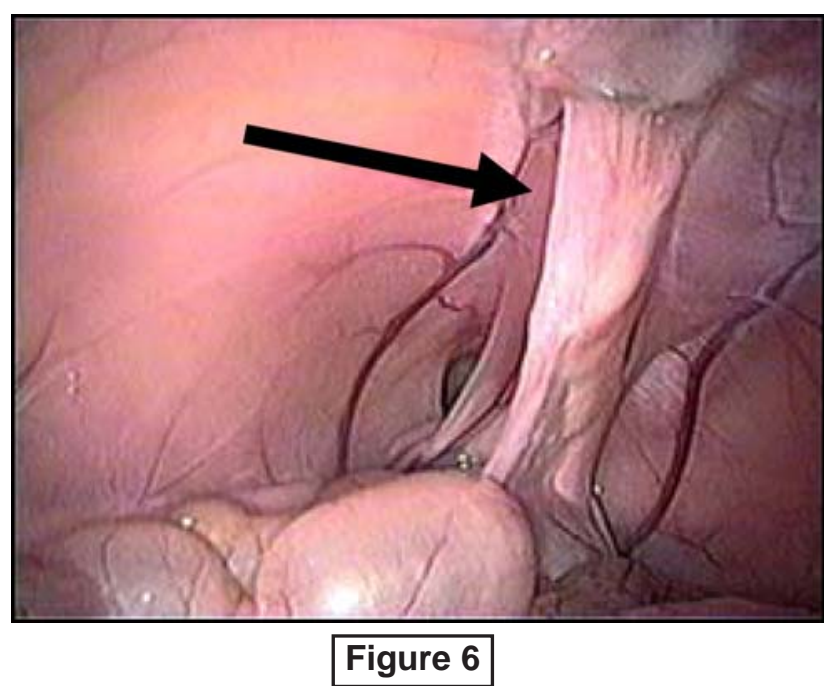

FIGURES 5 and 6 - Soft adhesions found at $28^{\text {th }}$ postoperative day, during laparoscopy (arrows). 


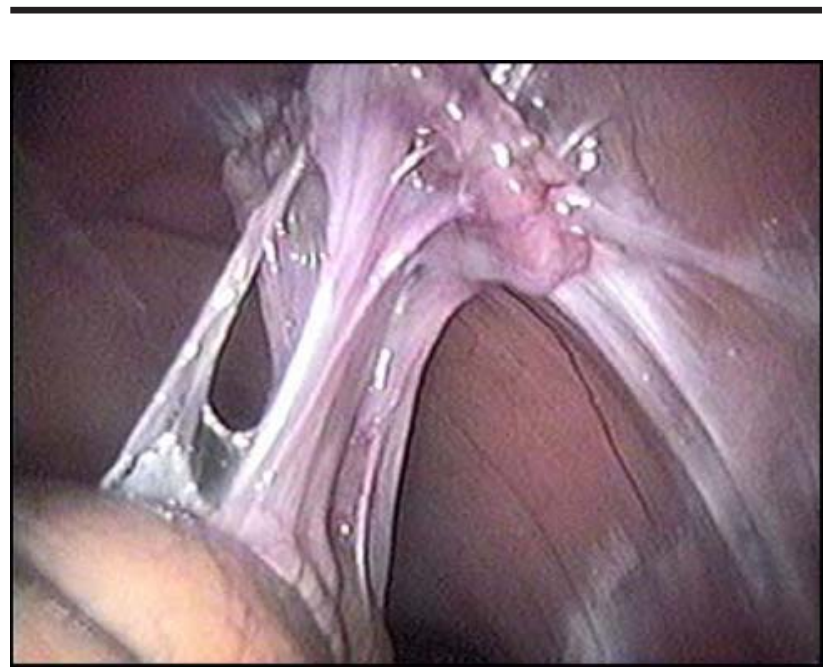

FIGURE 7 - Firm adhesions between the mesh and the bowel.

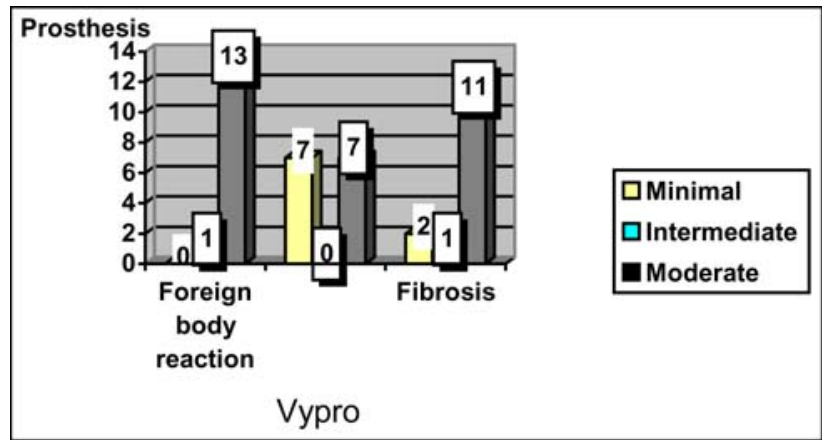

FIGURE 8 - Microscopical findings after Vypro mesh fixation.

In the polypropylene mesh tissue, foreign body reaction and inflammatory response were minimal whereas moderate degree of fibrosis was detected (Figure 9).

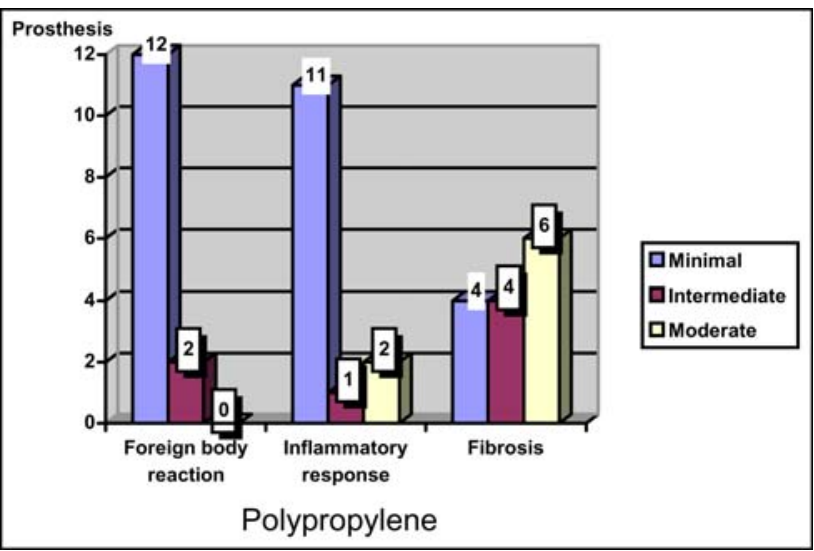

FIGURE 9 - Microscopical findings after polypropylene mesh fixation.
Macrophages accumulation and granulomatous foreign body reaction was predominantly intense in Vypro mesh, when compared to the polypropylene one. Chronic inflammatory response was less intense with polypropylene mesh, while the degree of fibroblasts proliferation a collagen fibers accumulation were higher in the Vypro mesh (Figures 10 and 11). The results of microscopically findings are summarized in Table 1.

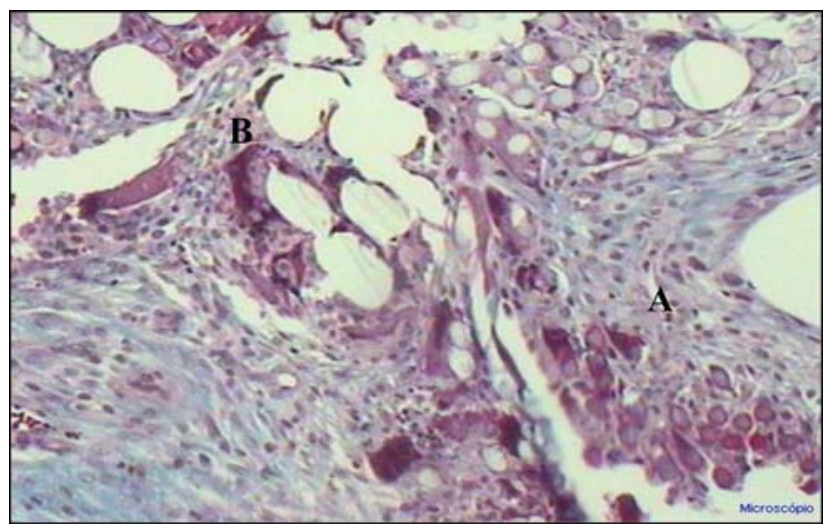

FIGURE 10 - Light microscopy findings after Vypro mesh fixation revealing moderate granulomatous foreign body reaction and moderate inflammatory response (A) with moderate fibrosis process (B) (100X).

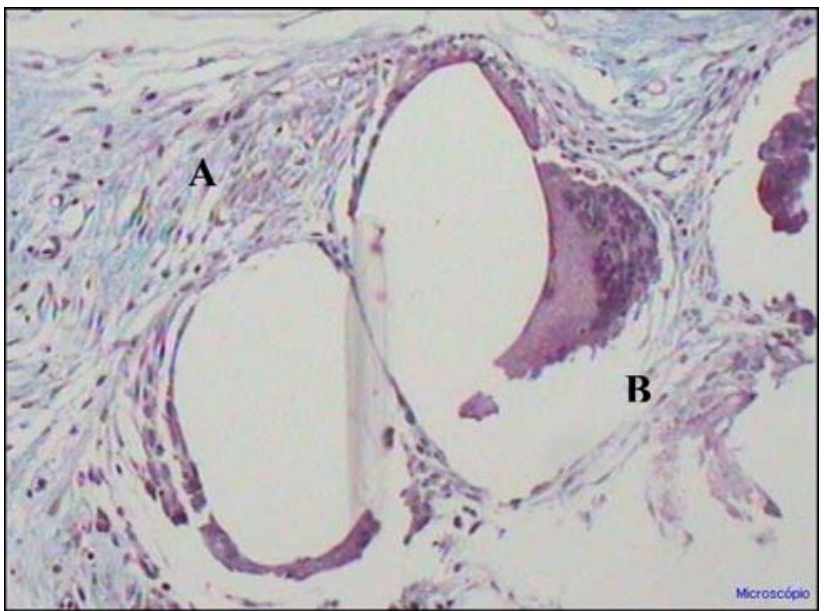

FIGURE 11 - Light microscopy findings after polypropilene mesh fixation revealing discreet granulomatous foreign body reaction and minimal inflammatory response $(\mathrm{A})$ with reduced fibrosis process $(\mathrm{B})(100 \mathrm{X})$. 
TABLE 1 - Microscopic analysis of Vypro and polypropilene mesh effects after abdominal wall fixation.

\section{MICROSCOPY}

\begin{tabular}{c|c|c|c|c}
\hline PROSTHESIS & & MINIMAL & $\begin{array}{c}\text { MINIMAL - } \\
\text { MODERATE }\end{array}$ & MODERATE \\
\hline \multirow{2}{*}{ VYPRO } & $\begin{array}{c}\text { GRANULOMATOUS FOREIGN } \\
\text { BODY REACTION }\end{array}$ & 0 & 1 & 13 \\
\cline { 2 - 5 } & INFLAMMATORY RESPONSE & 7 & 0 & 7 \\
\cline { 2 - 5 } & FIBROSIS & 2 & 1 & 11 \\
\hline \multirow{2}{*}{ MARLEX } & $\begin{array}{c}\text { GRANULOMATOUS } \\
\text { FOREIGN BODY REACTION }\end{array}$ & 12 & 2 & 0 \\
\cline { 2 - 5 } & INFLAMMATORY RESPONSE & 11 & 1 & 2 \\
\cline { 2 - 5 } & FIBROSIS & 4 & 4 & 6 \\
\hline
\end{tabular}

\section{Discussion}

Surgical treatment for inguinal hernia has undergone several changes during the last decade. New operative techniques such as tension-free open mesh repair and laparoscopic approaches have improved researches concerning groin hernia repair. For about a century, surgical treatment was based on suture repair of the hernial gap. Today, however, reinforcement of the groin region by alloplastic mesh materials is increasingly preferred. Nowadays, the introduction of biomaterials for inguinal hernia repair has become an integral component of surgery. Mesh implants are nowadays regarded as a standard treatment for this anatomic defect, and their routine use in the surgical practice is rapidly increasing ${ }^{6}$. In spite of markedly reducing recurrence rates and providing a tensionfree technique with reduced postoperative pain and faster recovery, this prosthetic material is linked to several complications. Tissue response at each interface of the polypropylene and Vypro prostheses used in this study was related to the structure of these biomaterials ${ }^{7}$. The polypropilene mesh, the most commonly applied mesh is reported to cause hardening, shrinking, chronic pain, adhesion formation and chronic foreign body reaction, as well as inflammatory process concerning epididimus and vas deferens ${ }^{8,9}$. Although these complications are relatively low considering the large number of meshes being implanted, common complications are observed in about half of the patients, including local wound disturbances, seromas in $30 \%-50 \%$, wound discomfort and stiffness of the artificial abdominal wall ${ }^{10}$. These side-effects are considered to be due to the important chronic inflammatory process to the nonresorbable mesh, basically affecting the integration of mesh fibers into recipient tissues. However, our study revealed the polypropylene mesh resulted in a lower degree of inflammatory response when compared to a partially absorbable mesh. On the other hand, the higher fibrosis degree found in the Vypro mesh implying in intense mesh incorporation had no relationship to this inflammatory reaction. It was hypothesized that the extent of the foreign body reaction with its provoked scar tissue depends on the amount and structure of the incorporated material. Thus, a mesh with a reduced amount of polypropylene material, higher elasticity and larger pores has been developed for inguinal hernia repair. This prosthetic material with low weight was exactly adapted to the physiology of the human abdominal wall in order to reduce chronic inflammatory response. By adding multifilament polyglactin to the polypropylene mesh, the mesh becomes partly absorbable. Nevertheless, the reduction of nonresorbable material is limited both by a required minimum strength and a minimum stiffness necessary for the handling by the surgeon, particularly during intraoperative placement and fixation.

The role of macrophages in scar formation is another important aspect, resulting in better integration of the biomaterials into the receptor tissue. It is well known that this integration is an effect either directly, through the production of substances such as tumor necrosis factoralpha, or indirectly, by stimulation of the production of glycans, fibroblastic growth factor, platelet-derived growth factor, and other substances by other cells ${ }^{11}$. Antimacrophage antibodies may produce abnormal scar formation, in experimental study ${ }^{11}$. Furthermore, this study revealed that foreign body granulomatous reaction was more intense in Vypro mesh and this fact is closely related to higher mesh incorporation process.

Adhesions formation, described as internal scars that form after trauma, represent a significant problem for the surgeon due to the morbidity associated with adhesive disease, including small bowel obstruction, difficulties in reoperative surgery and possibly chronic pain ${ }^{13}$. In our study, no intestinal obstruction was observed, but the short period of 28 days may not be enough to draw conclusions of this issue. Adhesions start with the development of a fibrin mesh followed by collagen bands on the third to fifth postoperative day and increase until the fourteenth day and stabilizes thereafter ${ }^{14}$ Thus, the interval period between the two procedures in our study seemed to be suitable to evaluate degree of adhesions, as well as the total amount. The present study revealed that the modified structure of the Vypro mesh had an important influence on the degree of abdominal adhesions, in spite of no significant difference in their amount. This data is somehow distinct from the reported by Zieren et al. ${ }^{15}$ who found no differences in 
both degree and amount of intraperitoneal adhesions in an experimental study in pigs. Another study revealed that the polyglactin 910 induced fibrotic adhesions at three months, until the complete absorption period. These data indicate that absorbable meshes cause fibrotic adhesions during the absorption process, but this reaction slows down gradually after absorption. ${ }^{16}$

Clinically, Vypro mesh became more firmly incorporated into the abdominal wall by dense fibrous tissue that infiltrates through the interstices due to the more intense foreign body reaction. As a result, mesh incorporation to the abdominal wall tissue was better with Vypro mesh. However, inflammatory response and fibrosis findings were discrepant to previous studies of different biomaterials. The main variants for these changes remain unclear, so further research is needed to verify these alterations.

\section{Conclusions}

Polypropylene and Vypro mesh, when implanted in the peritoneal cavity of rabbits provoke similar amount of adhesions. whereas the degree of this adhesions were lower in the Vypro mesh. Vypro mesh tissues had higher fibrosis, resulting in better mesh incorporation to the abdominal wall.

\section{References}

1. Metzger J, Lutz N, Laidlaw I. Guidelines for inguinal hernia repair in everyday practice. Ann R Coll Surg Engl. 2001;83:209-14.

2. Greenawalt KE, Butler TJ, Rowe EA, Finneral AC, Garlick DS and Burns JW. Evaluation of sepramesh biosurgical composite in a rabbit hernia repair model. J Surg Res.2000;94:92-8.

3. Marcondes W. Estudo dos efeitos das próteses de polipropileno revestidas com métodos de barreira implantadas na cavidade peritoneal de coelhos. [tese] São Paulo: Universidade Federal de São Paulo - Escola Paulista de Medicina; 2001.

4. Junge Karsten, Klinge U, Rosch R, Klosterhalfen and Schumpelick V. Functional and morphologic properties of a modified mesh for inguinal hernia repair. World J Surg. 2002;26:1472-80.

5. Shimanuki T, Nishimura K, Montz FJ, Zerega GS. Localized prevention of post surgical adhesion formation and reformation in oxidized regenerated cellulose. J Biomed Mater Res. 1987;22:173-85.

6. Schumpelick V, Conze J and Klinge U. Preperitoneal meshplasty in incisional hernia repair: a comparative retrospective study of 272 operated incisional hernias. Chirurg. 1996;67:1028-35.

7. Bellon JM, Bujan J, Contreras l. Integration of biomaterials implanted into abdominal wall: process of scar formation and macrophage response. Biomaterials. 1995;16:381-7.

8. Morris-Stiff GJ, Hughes LE. The outcomes of nonresorbable mesh placed within the abdominal cavity: literature review and clinical experience. J Am Coll Surg. 1998;186:352-67.

9. Goldenberg A, Matone J, Marcondes W. Effects of the polypropylene mesh in the testicle, epididimus and vas deferens of dogs. Acta Cir Bras. 2001;16:226-30.

10. Klinge U, Klosterhalfen b, Muller m, Anurov M, Ottinger A and Schumpelick V. Influence of polyglactin-coating on functional and morphological parameters of polypropylene-mesh modifications for abdominal wall repair. Biomaterials. 1999;20:613-23.

11. Bellon JM, Bujan J, Contreras LA, Carrera-San Martin A and Jurado F. Comparison of a new type of polytetrafluorethilene patch and polypropylene prosthesis for repair of abdominal wall defects. J Am Coll Surg. 1996;183:11-8.

12. Leibovich SJ and Ross R. The role of macrophage in wound repair. Am J Pathol. 1975;78:71-91.

13. Dinsmore RC and Caalton Prevention of adhesion to polypropylene mesh in a rabbit model. Am Surg. 1999;65:383-7.

14. Baykal A, Yorganci K, Sokmensuer C, Hamaloglu E, Renda N and Sayek I. An experimental study of the adhesive potential of different meshes. Eur J Surg. 2000;166:490-4.

15. Zieren J, Neuss H, Ablassmaier B and Muller JM. Adhesions after intraperitoneal mesh repair in pigs: prolene vs Vypro. J Laparoendosc Adv Surg Tech. 2002;12:249-52.

16. Baikal A, Onat D, Rasa K, Renda N and Sayek I. The effect of polyglycolic acid and polypropylene meshes on postoperative adhesion formation in mice. World $\mathrm{J}$ Surg. 1997;21:579-83.

\section{Correspondence:}

Alberto Goldenberg

Av. Albert Einstein, 627/1211

05651-901 São Paulo - SP

goldenb@terra.com.br
Conflict of interest: none Financial source: none

Received: April 18, 2005

Review: May 11, 2005

Accepted: June 14, 2005

\section{How to cite this article:}

Goldenberg A, Matone J, Marcondes W, Herbella FAM, Farah JFM. Comparative study of inflammatory response and adhesions formation after fixation of different meshes for inguinal hernia repair in rabbits. Acta Cir Bras. [serial on the Internet] 2005 Sept-Oct;20(5). Available from URL: http://www.scielo.br/acb. 